\title{
CARBON STORED BY FURNISHING WOOD-BASED PRODUCTS: AN ITALIAN CASE STUDY
}

\author{
Francesco Negro $^{1, \AA}$ Richard Bergman ${ }^{2}$
}

\begin{abstract}
The concentration of atmospheric carbon dioxide is constantly rising, with severe effects on global climate change. To mitigate impacts of climate change, the role of forest in terms of carbon sequestration are well-known as trees naturally pull $\mathrm{CO}_{2}$ from the atmosphere as they grow. Contrarily, only recently the carbon mitigation value of wood-based products in buildings has been recognized.

Buildings are a fundamental sector for wood-based products, both in terms of volume and service life length. In particular, furnishings in housing include high quantities of wood-based products; they are usually made, partly or entirely, by solid wood or by wood-based panels such as plywood, particleboard and medium density fiberboard. These wood furnishings store biogenic carbon during their service life. In this context, the present study investigated the amount of carbon stored by furnishing wood-based products for an apartment in Torino, Italy. The overall amount, determined according to European Standard, resulted in $3531 \mathrm{~kg}$ of $\mathrm{CO}_{2}$-equivalents stored. This corresponds to $45,8 \mathrm{~kg} / \mathrm{m}^{2}$ of indoor walkable area; simulating lower and higher intensity usages of wood-based products provided carbon storage values of 35,1 and $55,3 \mathrm{~kg} / \mathrm{m}^{2}$, respectively.

On the whole, the present study gave an order of magnitude of the role played in carbon storage by furnishing wood-based products in building and illustrates their relevance in mitigating climate change.
\end{abstract}

Keywords: Building, carbon mitigation value, climate change, furnishing, wood.

\section{INTRODUCTION}

Climate change is one of the main environmental challenges that modern society faces. Climate change impacts are strongly affecting the entire planet and, to mention some, include extensive droughts, catastrophic forest fires, melting of glaciers and extreme weather events (Hansen et al. 1981, Pachauri et al. 2014, Houghton 2015).

Anthropogenic greenhouse gas (GHG) emissions are the primary cause of climate change with land use changes and combustion of fossil fuels being the main source of emissions. Atmospheric carbon dioxide $\left(\mathrm{CO}_{2}\right)$ is one of the most important GHG both for its role in heating Earth and for the impact that humans have on its concentration (Hansen et al. 1981, Anderson et al. 2016). Starting from the beginning of the 1900s, the human activity has caused a dramatic increasing in the concentration of atmospheric $\mathrm{CO}_{2}$ which has recently exceeded $400 \mathrm{ppm}$ and likely to reach $1000 \mathrm{ppm}$ or higher by 2100 unless measures to mitigate GHG emissions are taken (Forster et al. 2007, Pachauri et al. 2014, SCRIPPS 2018, NOAA 2018). 
Adopting and enhancing $\mathrm{CO}_{2}$ mitigation strategies are absolutely necessary to limit the global effects of climate change (Friedlingstein et al. 2011; Pilli et al. 2015). $\mathrm{CO}_{2}$ mitigation strategies include GHG emissions reduction by using non- $\mathrm{CO}_{2}$-emitting energy sources (e.g. solar and wind), capturing emitted $\mathrm{CO}_{2}$ through natural processes of photosynthesis in plants through reforestation and afforestation along with man-made processes, and finally (biogenic) carbon storage via harvested wood products (Thomas 2001, McKinley et al. 2011, Lippke et al. 2011, Williamson 2016, Geng et al. 2017). Through photosynthesis, growing trees absorb carbon dioxide to form their tissues. Once formed, the $\mathrm{CO}_{2}$ is fixed as biogenic carbon in wood and in the wood-based products (WBPs) made from the wood. The carbon storage lasts until the WBPs are decomposed or burned, releasing $\mathrm{CO}_{2}$ and other GHGs back to the atmosphere (Bergman et al. 2013). The environmental value of forests in terms of carbon sequestration is well-known, while more attention has recently been paid to wood and wood-based products (Bergman et al. 2014, Miner et al. 2014, Thonemann and Schumann 2016; Vitale and Arena 2018). From the static viewpoint of time, the biogenic $\mathrm{CO}_{2}$ emissions released during WBP production are more than balanced out from forest carbon uptake during tree growth assuming the forest regrows to its original state. This occurs even if the GHG fluxes from re-sequestering forest carbon occur outside the given time horizon for calculating the impact on climate change which is typically 100 years (Bergman 2012, Salazar and Bergman 2013, IPCC 2014). For a carbon storage frame of reference, in the United States, an average single family house of $233-\mathrm{m}^{2}$ in 2012 contains roughly 22000 ovendried $\mathrm{kg}$ of structural wood elements (Meil et al. 2004, McKeever and Elling 2015, McKeever and Elling 2018). Therefore, a $233-\mathrm{m}^{2}$ home could store $11000 \mathrm{~kg}$ or about $50 \mathrm{~kg} / \mathrm{m}^{2}$ of carbon assuming wood carbon content at $50 \%$ and excluding adhesives. This value does not include nonstructural wood products, which may have a shorter service life (Smith et al. 2006, Skog 2008, Elling and McKeever 2018). Service life of structural wood products tends to match the service life of the structure itself. Therefore, given a median life of 80 years for a single family home (Skog 2008), the stored carbon can last from two to three forest rotation cycles of intensely managed, highly productive forests (O'Connor 2004, Smith et al. 2006). Typical single-family houses in the U.S. at $233-\mathrm{m}^{2}$ can be twice as large as housing in Italy (Cannari and Faiella 2008, McKeever and Elling 2015, US Department of Commerce 2017). Thus, also considering the different construction typologies, structural elements of typical Italian single-family houses constructed from wood could store less than $2800 \mathrm{~kg}$ of carbon.

The value of carbon storage performed by wood and WBPs mainly depends on density, volume, wood percentage and service life length. The higher the density of wood, the higher the amount of carbon stored in it on a volume basis. For many wood species, carbon constitutes about $50 \%$ the weight of wood on an oven-dried basis; this value is commonly used for analyses on carbon storage, even if differences among wooden species exist (Gang et al. 2017, EN 16449:2014, Thomas and Martin 2012). Secondly, everything else being equal, a higher volume of furnishing WBPs means a higher amount of carbon stored. Similarly, a higher percentage of wood in a WBP, in case where the product is not entirely made by solid wood, means a higher carbon storage value for a given volume. This applies both to semi-finished and finished products; for instance, plywood is mostly wood but part resin.

Finally, a longer service life of WBPs determines a longer, and thus more valuable, storage period because this keeps the carbon in the wood in a stable carbon pool. Correspondingly, finding the half-life of individual furnishing WBPs can be difficult to find but Smith et al. (2006) estimated the half-life of U.S. household furniture at 30 years. Any efforts to increase the half-life would increase pool of carbon storage in WBPs thus reducing carbon (i.e. GHG) emissions in the atmosphere.

The amount of WBPs used in building can reach very high levels depending on housing types. Their service life length is also often relevant, since wooden products usually remain in buildings for decades and even centuries especially structural elements (Aktas et al. 2012, Takano et al. 2015). Recently, the building sector has paid an increasing attention to the environmental aspects and their interest in WBPs has grown because of wood's unique ecological profile (Ramage et al. 2017, Theoman et al. 2010, Resch 2008). WBPs can be divided in two categories: structural (i.e. framing lumber, panel products, solid wood beams, cross laminated limber, etc.) and non-structural (i.e. furniture, flooring, doors and windows etc.).

In this context, the present paper investigated the amount of carbon stored by non-structural WBPs in a furnished apartment located in Torino, Italy. The furnishings selected for analysis were flooring, 
chairs, tables, closets, kitchen furniture, beds and doors. The amount of carbon stored was determined according to the calculation method provided by EN 16449:2014. The (base-case) furnished apartment was considered as a 'mid-intensity' usage of WBPs as mentioned previously.

The results provided for the first time the magnitude of carbon stored in furnishings for an actual apartment. This enables a better understanding of the relevance of non-structural WBPs used in the building sector.

\section{MATERIALS AND METHODS}

The chosen apartment was located in the metropolitan area of Torino in northern Italy. It covers a total walkable area of $88,5 \mathrm{~m}^{2}\left(76,7 \mathrm{~m}^{2}\right.$ indoor and $11,8 \mathrm{~m}^{2}$ outdoor $)$. It is inhabited and included furnishings such as chairs, beds, flooring, doors, etc. (Figure 1 and Table 1). Some furnishings were made of solid wood coming from regional commercial wood species traditionally used in making furnishings, such as sweet chestnut (Castanea sativa), European oak (Quercus petraea) and European walnut (Juglans regia). Other furnishings, instead, are entirely or partly made of wood-based panels (plywood, particleboard and medium density fiberboard (MDF)).

Reference examples of residential furnishing in northern Italy are not available, due to the large amount of variables involved. Anyway, the apartment selected contains the typical furnishings that one can expect in residential housing in this region. For instance, taking student housing as a specific case of residential housing, the furnishings of the apartment are in line with those envisaged by the "rental agreement type" of the City of Padova, northern Italy, for a type apartment to be rented to students (Comune di Padova 2017).

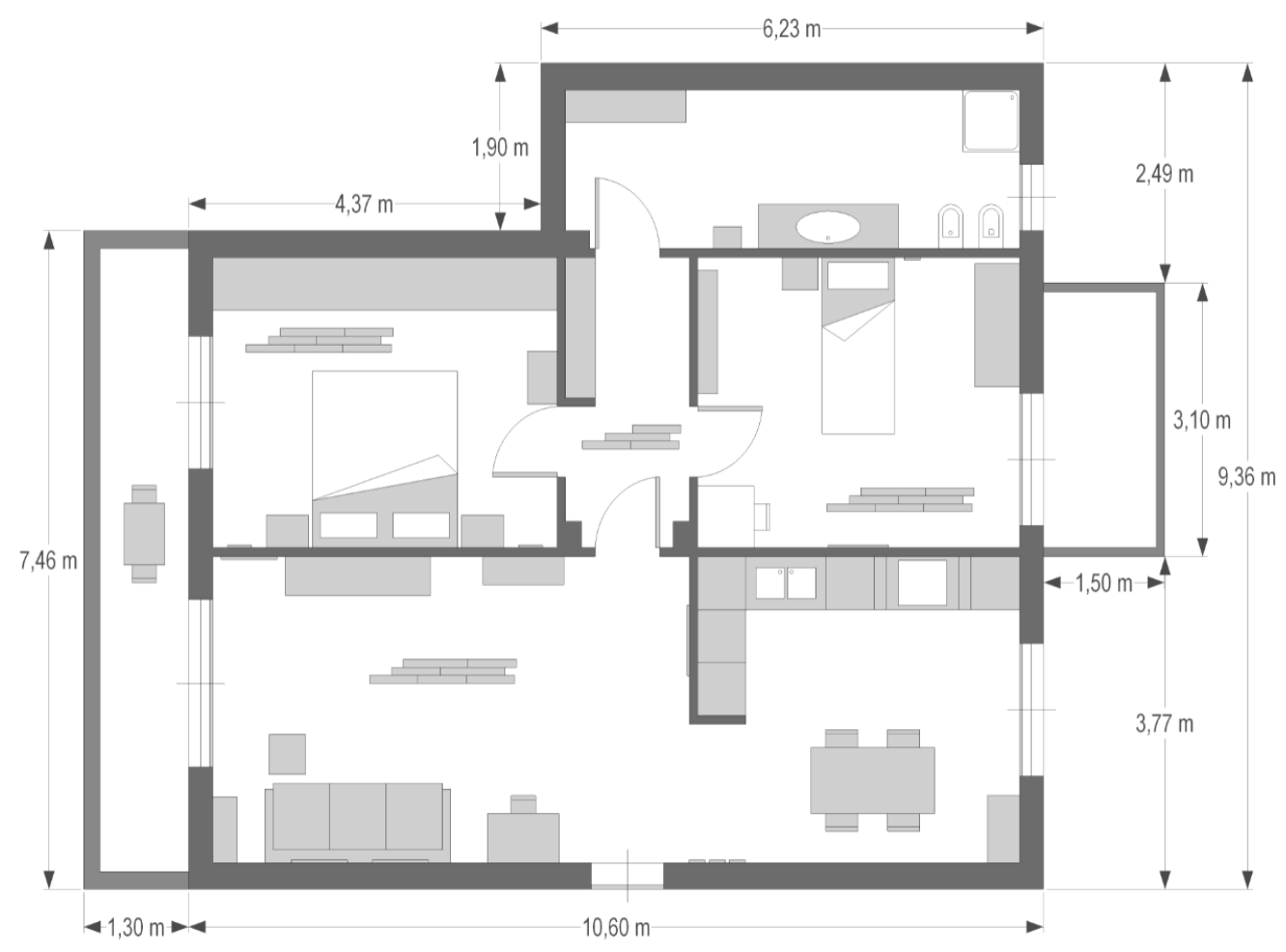

Figure 1: Floor plan of the apartment chosen as a case study. Wood based products are colored in light grey. All furnishings are drawn in scale, except for frames that have been enlarged to be more visible. Baseboard is not shown for easier readability, anyway it is present in each room in which parquet flooring is illustrated. Grey color on windows represents the roller shutter boxes. 
Table 1: Furnishings in the apartment: type, position (K: kitchen, L: living room, D: double bed room, S: single room, C: corridor, B: bathroom, BC: balconies, O: overall, W: windows), gross length, width and height, in mm, effective volume of WBPs embedded, in $\mathrm{m}^{3}$, and wood species or WBPs; s3 indicates WBPs added for simulating the scenario 3.

${ }^{1}$ Eu: European.

\begin{tabular}{|c|c|c|c|c|c|c|c|}
\hline $\begin{array}{l}\text { Position, } \\
\text { Furnishing }\end{array}$ & $\begin{array}{l}\text { Gross } \\
\text { dimensions } \\
(h \mathrm{bov} h, \mathrm{~mm})\end{array}$ & $\begin{array}{c}\text { WBPs } \\
\text { volume } \\
\left(\mathrm{m}^{3}\right)\end{array}$ & $\begin{array}{l}\text { Wood } \\
\text { species or } \\
\text { WBPs }{ }^{1}\end{array}$ & $\begin{array}{l}\text { Position, } \\
\text { Furnishing }\end{array}$ & $\begin{array}{l}\text { Gross } \\
\text { dimensions } \\
(h \mathrm{w} w \mathrm{xh}, \mathrm{mm})\end{array}$ & $\begin{array}{c}\text { WBPs } \\
\text { volume } \\
\left(\mathrm{m}^{3}\right)\end{array}$ & $\begin{array}{l}\text { Wood sp exies } \\
\text { or WBPs }\end{array}$ \\
\hline O. parquet & $7260 \times 7260 \times 125$ & 0,659 & $\begin{array}{l}\text { birch and Eu } \\
\text { oakplywood }\end{array}$ & S, night table & $450 \times 350 \times 380$ & 0,010 & particlebcard \\
\hline O. baseboard & $45930 \times 10 \times 80$ & 0,037 & $\begin{array}{l}\text { birch and Eu } \\
\text { oakplywood }\end{array}$ & S. closet & $1400 \pi 500 \pi 2000$ & 0.124 & Eu walnut \\
\hline $\begin{array}{l}\text { O. inner doors } \\
\text { and frames }\end{array}$ & $800 \times 35 \times 2140$ & 0.195 & $\begin{array}{l}\text { Scots pine } \\
\text { MDF }\end{array}$ & S, boolrase & $1420 \pi 250 \pi 900$ & 0,026 & spruce \\
\hline 0. shutter baxes & $1500 x 400 x 8$ & 0,085 & poplar plywood & D. bed & $2000 \times 1800 \times 300$ & 0.080 & $\begin{array}{l}\text { particleboard } \\
\text { beech plywood } \\
\text { MIF }\end{array}$ \\
\hline O. frames & various & 0,006 & $\begin{array}{l}\text { cherry, spruce } \\
\text { MIDF }\end{array}$ & D right tables & $520 \times 380 \times 530$ & 0.040 & spruce \\
\hline I. entry door & $900 \times 10 \times 2100$ & 0.019 & Eu cak & D. commode & $600 \times 370 \times 1110$ & 0.051 & spruce \\
\hline L. TV stand & $1800 x 440 x 450$ & 0,034 & particlebcard & D. wardrobe & $4270 \pi 600 \pi 2900$ & 0.556 & $\begin{array}{l}\text { spruce } \\
\text { particleboard }\end{array}$ \\
\hline I. shelves & $\begin{array}{l}800 \times 250 \times 100 \\
(x 4)\end{array}$ & 0,080 & particleboerd & $\mathrm{K}$ furniture & $4019 \times 600 \pi 960$ & 0.407 & particlebcard \\
\hline I., bookcase & $1000 \times 350 \times 3000$ & 0.110 & Eu valnut & $\mathrm{K}$ table & $1530 \pi 750 \pi 770$ & 0,042 & sweet chestnut \\
\hline L. smatl table & $450 \times 450 \times 535$ & 0,004 & Eu valnut & $\mathrm{K}$ chairs & $460 \times 400 \times 660$ & 0.021 & beech \\
\hline L, showcase & $750 \times 300 \times 1650$ & 0,020 & $\begin{array}{l}\text { sweet chestnut, } \\
\text { particleboard }\end{array}$ & $\mathrm{K}$ closet & $760 \times 400 \times 1300$ & 0,045 & particlebcard \\
\hline L, chair & $440 \times 420 x 900$ & 0,005 & Eu cak & B. sink cabinet & $1740 \pi 500 \pi 500$ & 0.041 & $\begin{array}{l}\text { particlebcard } \\
\mathrm{MDF}\end{array}$ \\
\hline I. writing desk & $880 x 440 x 580$ & 0.025 & $\begin{array}{l}\text { Eu valnut } \\
\text { spruce }\end{array}$ & B. closet & $1500 \pi 370 \pi 2000$ & 0,079 & $\begin{array}{l}\text { Scots pine } \\
\text { MDF }\end{array}$ \\
\hline I. couch & $2200 \times 600 \times 1250$ & 0,106 & particlebcard & B, ladder & $340 \times 250 \times 1500$ & 0,020 & beech \\
\hline BC, chairs & $\begin{array}{l}440 x 420 \times 900 \\
(x 2)\end{array}$ & 0,010 & Scots pine & \multicolumn{4}{|c|}{ SCENARIO 3} \\
\hline$B C$, table & $700 \times 500 \times 515$ & 0,005 & Scots pine & $\begin{array}{l}\text { Os3, windows } \\
\text { and frames }\end{array}$ & various & 0,478 & spruce \\
\hline C., closet & $2000 \times 370 \times 2900$ & 0,143 & $\begin{array}{l}\text { particleboard } \\
\text { MIDF }\end{array}$ & Os3, plywood & $8760 x 8760 \times 125$ & 0,959 & $\begin{array}{l}\text { birch and Eu caks } \\
\text { plywood }\end{array}$ \\
\hline S. bed & $2000 \times 900 \times 300$ & 0,031 & $\begin{array}{l}\text { Scots pine } \\
\text { beech plywood }\end{array}$ & Os3, beseboard & $65390 \times 10 \times 80$ & 0.052 & $\begin{array}{l}\text { birch and Eu caks } \\
\text { plywood }\end{array}$ \\
\hline
\end{tabular}

Scenarios were developed with scenario (2) as the base case, the Italian apartment. The scenarios based on amount of wood furnishings were as follow: (1): low-intensity, (2) medium-intensity, and (3) high-intensity. Scenario 1 simulates the replacement of a (wood) parquet flooring system with a non-wooden flooring system to reduce overall wood volume whereas scenario 3 increased overall wood volume by adding both solid wood windows and parquet flooring systems to other areas of the apartment, the kitchen and bathroom not installed in scenario 2 .

According to the calculation method provided by EN 16449:2014, the amount of $\mathrm{CO}_{2}$-equivalents $\left(\mathrm{CO}_{2}-\mathrm{e}\right)$ stored by each WBP is determined by Equation $1 . \mathrm{CO}_{2}$-e or carbon dioxide equivalent, is a standard unit for measuring carbon footprints:

$$
W B P_{C_{2}}=3,67 x 0,5 \frac{\rho_{\omega} V F_{w}}{1+\frac{\omega}{100}}
$$

where $W B P_{C O}$ is the amount, in $\mathrm{kg}$, of $\mathrm{CO}_{2}$-e stored by a WBP 3,67 is the ratio between the molecular weight of $\mathrm{CO}_{2}$ and the atomic weight of $\mathrm{C} 0,5$ is the fraction in weight of $\mathrm{C}$ in wood as given by EN 16449:2014, $r$ is the density of wood in $\mathrm{kg} / \mathrm{m}^{3}$ at moisture content on dry basis $\left(\mathrm{MC}_{\mathrm{db}}\right) w, V$ is the volume, in $\mathrm{m}^{3}$, occupied by the WBP, $F$ is the fraction of wood in $V, \omega$ is the MC, in percentage, of wood in the product. All calculation provided used MC on a dry basis. MC does not impact the carbon content of the wood structure itself but size does fluctuate as MC changes.

The variables included in Equation $1(r, V, F, \omega)$ were determined for each WBP included in the apartment, then the relative amount of $\mathrm{CO}_{2}$ stored was calculated. The determination methods differed 
depending on the type of WBP and are described as the following.

\section{Solid wood}

Since it was not possible to remove physical samples from the furnishings without damaging them, wood species for the furnishings were firstly macroscopically identified and then the density $(r)$ of the wood was set according to the average reference values at $12 \%$ of MC given by Giordano (1997), the density values were adjusted according to Simpson (1993), depending on the MC of wood in the furnishings.

The MC $(\omega)$ of solid wood was determined through a contact hygrometer with accuracy $\pm 0,1 \%$. When direct measurement of MC was not possible, reference values given for WBPs in residential and indoor environments were used (Bergman 2010, EWPAA 2008).

The volume $(V)$ of solid wood in furnishings was calculated by summing the volumes of all the components made of solid wood embedded in it, according to Equation 2:

$$
V_{s w}=l_{1} w_{1} t_{1}+l_{2} w_{2} t_{2}+\ldots+l_{n} w_{n} t_{n}
$$

where $\mathrm{V}_{\text {ww }}$ is the volume, in $\mathrm{mm}^{3}$, of solid wood embedded in an artifact, and $l, w$ and $t$ are respectively the length, width and thickness, in $\mathrm{mm}$, of the solid wood components $1,2 \ldots$ embedded in the artifact.

Length, width, and thickness of all WBPs were determined in mm through a measuring tape in Class II of the European Weights and Measure Regulation.

\section{Plywood}

The density of wood embedded in plywood depends on the wood species and on the densification determined by the pressing phase in plywood production. To the purpose of this study the densification was considered of 4\% according to Wang et al. (2006) and Wellons et al. (1983), and the density of wood constituting plywood was therefore calculated by Equation 3:

$$
\rho_{w p}=\rho_{r} x 1,04
$$

where $\rho_{w p}$ is the density of wood included in plywood, $r_{r}$ is the density of the wood species given by references 1,04 is the coefficient taking into account the densification of wood in plywood.

The volume $(V)$ of plywood in furnishings were calculated as already reported in Equation 2 for solid wood.

As for the percentage of wood $\left(F_{w}\right)$ in plywood, it is to consider that part of its volume was composed of resins (i.e. glue). To calculate the overall volume of the glue, the glue line thickness (which varies depending on pressure, glue etc.) was set to $0,1 \mathrm{~mm}$ according to Kurt and Cil (2012) and Baldwin (1995); the number of the glue lines was directly calculated since it was always possible seeing the cross section of plywood. The percentage of wood in plywood was then calculated, referring to its cross section, according to Equation 4:

$$
F_{w p}=\frac{t_{p}-\left(\mathrm{t}_{\mathrm{gl}} \mathrm{n}_{\mathrm{gl}}\right)}{t_{p}} \times 100
$$

where $F_{w p}$ is the percentage of wood in the cross section of the WBP, $T_{p}$ is the thickness of plywood, $T_{g l}$ is the thickness of each glue line, $n_{g l}$ is the number of glue lines.

The MC $(\omega)$ of wood in plywood was measured as already reported for solid wood. 


\section{Particleboard and MDF}

Particleboard and MDF are made of wood and resin and produced with different densities and with final MC of about 10\%, similar to that commonly found in indoor housing (Bergman 2010, EWPAA 2008).

To the purpose of this study, it was considered, according to Wilson 2010a, Wilson 2010b that $1 \mathrm{~m}^{3}$ of particleboard and MDF have an oven-dried density of 671 and $666 \mathrm{~kg} / \mathrm{m}^{3}$, respectively. The above values already take into account the fraction of wood lost as waste during manufacturing. Overall, for particleboard the Equation 1 can be rewritten as follows (Equation 5):

$$
P a_{\mathrm{CO}_{2}}=3,67 \times 0,5\left(671 V_{p}\right)
$$

where $\mathrm{Pa}_{\mathrm{CO}_{2}}$ is the amount, in $\mathrm{kg}$, of $\mathrm{CO}_{2}$-e stored by particleboard 3,67 and 0,5 are the coefficient already defined in Equation 1, 746 is the content, in $\mathrm{kg}$, of wood in $1 \mathrm{~m}^{3}$ of particleboard and $V_{p}$ is the volume of the panel considered.

Similarly, for MDF the Equation 1 can be rewritten as follows (Equation 6):

$$
M D F_{\mathrm{CO}_{2}}=3,67 \times 0,5\left(666 V_{p}\right)
$$

where $\mathrm{MDF}_{\mathrm{CO}_{2}}$ is the amount, in $\mathrm{kg}$, of $\mathrm{CO}_{2}$-e stored by MDF 3,67 and 0,5 are the coefficient already defined in Equation 1, 741 is the content, in $\mathrm{kg}$, of wood in $1 \mathrm{~m}^{3}$ of MDF and $V_{p}$ is the volume of the panel considered.

All of the above methods were used for calculating the $\mathrm{C}$ stored by WBPs included in the apartment (scenario 2). For solid wood windows added to scenario 3, the dimensions, the density and the MC were set using the values given by data sheets of products commonly available on the market.

\section{RESULTS AND DISCUSSION}

First, each atom of $\mathrm{C}$ in wood subtracts from the atmosphere its entire molecule of $\mathrm{CO}_{2}$ of origin. Therefore, because the molecular weight of $\mathrm{CO}_{2}$ is substantially higher than the atomic weight of $\mathrm{C}$, wood stores higher amount of $\mathrm{CO}_{2} \mathrm{e}$ than its own weight: for instance, through Equation 1 it can be calculated that $1 \mathrm{~m}^{3}$ of wood with density of $500 \mathrm{~kg} / \mathrm{m}^{3}$ at $12 \%$ of $\mathrm{MC}$ stores $818 \mathrm{~kg}$ of $\mathrm{CO}_{2}$-e, which is about 1,8 times its own oven-dried weight.

As for the results of the study, Figure 2 shows part of the living room to exemplify the measurements and calculations performed in the entire apartment.

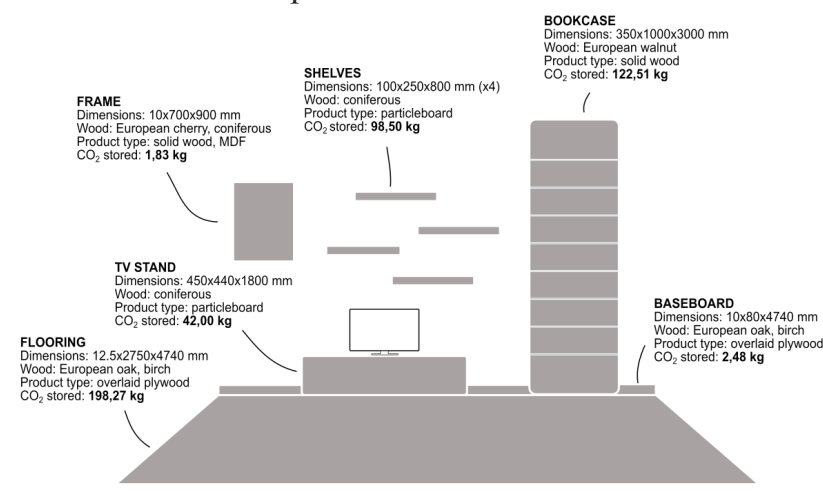

Figure 2: Part of the living room with all furnishings embedding WBPs colored in grey. Dimensions, wood species, WBP typology and $\mathrm{kg}$ of $\mathrm{CO}_{2}$ stored are indicated for each of them. 
Overall, the considered WBPs store $3531 \mathrm{~kg}$ of carbon dioxide. This amount is exclusively related to WBPs, whereas more carbon was stored or sequestered in the apartment by other objects, such as upholstery materials or houseplants, was outside the analysis of the present study. Carbon studies often compare the carbon stored with $\mathrm{CO}_{2}$ emitted from cars; in this sense, the storage in the apartment corresponds to the $\mathrm{CO}_{2}$ emitted by about 3 cars driving $10000 \mathrm{~km}$ in a year and emitting $120 \mathrm{~g}$ of $\mathrm{CO}_{2}$ per km (European Environment Agency 2016).

The carbon stored in the apartment has some uncertainty because the densities of wood was taken from reference values that generally are listed with broad ranges to account for the variability of wood. These variances were investigated and did not result in large changes in the total amount of carbon stored. For example, the table in the kitchen was made of $0,042 \mathrm{~m}^{3}$ of sweet chestnut. Given a literature density of $572 \mathrm{~kg} / \mathrm{m}^{3}$ at $8,8 \mathrm{MC}$, the carbon stored in it amounts to $40,62 \mathrm{~kg} \mathrm{CO}$-e. Considering the variability of wood, the density of sweet chestnut was altered by $\pm 50 \mathrm{~kg} / \mathrm{m}^{3}$ at the same MC (respectively, $522 \mathrm{~kg} / \mathrm{m}^{3}$ and $\left.622 \mathrm{~kg} / \mathrm{m}^{3}\right)$. The carbon stored varied from $37,07 \mathrm{~kg}$ to $44,17 \mathrm{~kg}( \pm 8,7$ $\%)$. Applying this approach to each WBP indicated the overall value of $3531 \mathrm{~kg}$ of carbon stored in the apartment varied from $3224 \mathrm{~kg}$ to $3838 \mathrm{~kg}$.

Regarding the other variables in Equation 1, variations in MC had no impact in this case study, since in indoor housing the equilibrium MC (EMC) mainly ranges from $6 \%$ to $10 \%$ (Bergmann 2010). Furthermore, although the water contained within the WBP could increase and decrease base on surrounding EMC, the mass of carbon within the WBP does not change. As for the volume of WBPs, variations due to uncertainty of measurement are negligible in the context of the present study.

As for the contribution per WBP, almost half $(46,6 \%)$ of the carbon was stored by particleboard, followed by plywood and solid wood $24,9 \%$ and $21,6 \%$, respectively whereas MDF accounts for just the $6,9 \%$. These fractions, however, strictly depend on the composition of the various furnishings and could have been very different. For instance, replacing the $12,5 \mathrm{~mm}$ thick plywood parquet flooring with a $12 \mathrm{~mm}$ thick laminate flooring would slightly change the overall amount of carbon stored (from $801 \mathrm{~kg}$ to $760 \mathrm{~kg} \mathrm{CO}_{2} \mathrm{e}$ ) in the apartment, whereas the fractions per flooring product would be substantially different.

Storage fractions per furnishing provide a more stable indication, because in this case their overall volume, which has a remarkable relevance in Equation 1, is fixed. Grouping the furnishings in categories (Figure 3 ) shows that the closets store the $35,9 \%(1266 \mathrm{~kg})$, and the wardrobe alone the $17,7 \%(624 \mathrm{~kg})$; the parquet and baseboard store the $23,4 \%(826 \mathrm{~kg})$, the kitchen furniture the 11,7 $\%(414 \mathrm{~kg})$, the inner and entry doors the $6,9 \%(244 \mathrm{~kg})$, the bookcases the 4,0\% (142 kg), the beds and couch a similar fraction (respectively $3,7 \%$, i.e. $131 \mathrm{~kg}$, and 3,6 \%, i.e. $128 \mathrm{~kg}$ ). Other furnishings store more limited amounts.

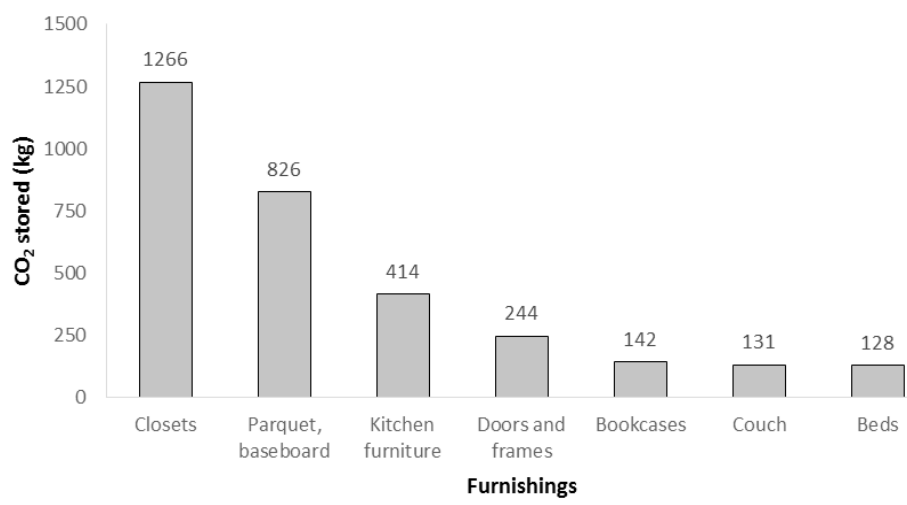

Figure 3: Main categorıes oг wood pasea rurnısnings, in terms ог $\mathrm{kg}$ ог $\iota_{2}$ storea, included in the apartment. 
For those wooden species having higher commercial value (European oak, sweet chestnut, European walnut and cherry), they store the $17,8 \%(628 \mathrm{~kg})$ of the overall amount; in particular, the main fraction is represented by European oak of the parquet flooring $(7,6 \%$, i.e. $268 \mathrm{~kg})$. This limited amount reflects the fact that, in furnishing, the more expensive woods usually occupy minor volumes compared to cheaper woods.

As for scenarios 1, 2 and 3, removing the parquet flooring (scenario 1) determined a reduction of $23,4 \%$, whereas adding solid wood windows made of spruce, and parquet flooring (the same laid in the other rooms) in the bathroom and in the kitchen (scenario 3) increased the amount of 20,7 \%. Overall, considering the indoor walkable area, the storage ranged from $35,1 \mathrm{~kg} / \mathrm{m}^{2}(2705 \mathrm{~kg})$ of scenario 1 , to $45,8 \mathrm{~kg} / \mathrm{m}^{2}(3531 \mathrm{~kg})$ of scenario 2 and up to $55,3 \mathrm{~kg} / \mathrm{m}^{2}(4260 \mathrm{~kg})$ of scenario 3 . It is also to note that wooden windows added in scenario 3 would store $354 \mathrm{~kg}$, representing the fourth main furnishing in terms of storage behind kitchen furniture (see Figure 3).

\section{CONCLUSIONS}

Reducing the concentration of atmospheric carbon dioxide is a fundamental challenge for the twenty-first century. Developing and identifying GHG mitigation strategies are vital to mitigating the impacts from climate change from increasing $\mathrm{CO}_{2}$ level. One approach is quantifying the potential of carbon stored in wood products such as furnishings. Through the analysis of a case study, the present work investigated the carbon storage of furnishing WBPs. For the chosen apartment, the total amount of carbon stored by WBPs resulted in $3531 \mathrm{~kg} \mathrm{CO}_{2} \mathrm{e}$, which correspond to $45,8 \mathrm{~kg} \mathrm{CO}_{2} \mathrm{e} / \mathrm{m}^{2}$ of indoor walkable area. Lower and higher usage scenarios, simulated by removing or adding WBPs, resulted in storages of $35,1 \mathrm{~kg}$ and $55,3 \mathrm{~kg} \mathrm{CO} 2 / \mathrm{m}^{2}$ respectively. Carbon stored can be even higher, to mention some example, in apartments embedding exterior wooden claddings, as often happens in mountain areas, or structural WBPs. The potential substantial level of this carbon pool along wood structural elements ought to be considered when developing strategies on mitigating climate change.

Matching the above data with the number of apartments included in a metropolitan city illustrates the considerable relevance of furnishing WBPs in terms of carbon storage. Anyway, broad estimates should be taken with caution since many variables involved shall be carefully assessed, such as mean squared meters per apartment or furnishing types. Therefore, other studies are worthy of further investigation, for instance regarding housing types, furnishing styles and structural wood-based products.

\section{REFERENCES}

Aktas, C.B.; Bilec, M.M. 2012. Impact of lifetime on US residential building LCA results. International Journal of Life Cycle Assessment 17(3):337-349.

Anderson, T.R.; Hawkins, E.; Jones, P.D. 2016. $\mathrm{CO}_{2}$, the greenhouse effect and global warming: from the pioneering work of Arrhenius and Callendar to today's Earth System Models. Endeavour 40(3):178-187.

Baldwin, R.F. 1995. Plywood and veneer-based products. Manufacturing practices. Miller Freeman Inc., San Francisco.

Bergman, R. 2010. Drying and control of moisture content and dimensional changes. In: Wood handbook-Wood as an engineering material. U.S. Department of Agriculture, Forest Service, Forest Products Laboratory, Madison. 
Bergman, R. 2012. The effect on climate change impacts for building products when including the timing of greenhouse gas emissions. Ph.D. Dissertation. Madison, WI: University of Wisconsin. 278 p.

Bergman, R.; Falk, R.; Salazar, J.; Gu, H.; Napier, T.; Meil, J M. 2013. Life-cycle energy and GHG emissions for new and recovered softwood framing lumber and hardwood flooring considering end-of-life scenarios. Research Paper FPL-RP-672. Madison, WI: U.S. Department of Agriculture, Forest Service, Forest Products Laboratory. 33 p

Bergman, R.; Puettman, M.; Taylor, A.; Skog, K. 2014. The carbon impacts of wood products. Forest Products Journal 64(7/8): 220-231.

Cannari, L.; Faiella, I. 2008. House prices and housing wealth in Italy. Bank of Italy, Temi di Discussione (Working Paper) No. A4. 31 pp.

Comune di Padova. 2017. Contratti di locazione (contratti tipo). Available $<$ http://www.padovanet. it/informazione/contratti-di-locazione-contratti-tipo\#5104> (accessed on 03.12.2018)

Elling, J.; McKeever, D.B. 2018. Wood products used in residential repair and remodeling in the United States, 2014. General Technical Report FPL-GTR-256. Madison, WI: U.S. Department of Agriculture, Forest Service, Forest Products Laboratory. 31 p.

European standard. EN. 2014. Wood and wood-based products - Calculation of the biogenic carbon content of wood and conversion to carbon dioxide EN 16449. 2014.

European Environment Agency. 2016. Monitoring $\mathrm{CO}_{2}$ emissions from new passengers' cars and vans in 2015. EEA Report n. 27/2016.

Engineered Wood Products. EWPAA. 2008. Facts about particleboard and MDF. Australian Wood Panels Association Incorporated, Coolangatta. Available <https:/www.yumpu.com/en/ document/view/39274817/facts-about-particleboard-and-mdf-engineered-wood-products- $>$ (accessed on 03.12 .2018 )

Forster, P.; Ramaswamy, V.; Artaxo, P.; Bernsten, T.; Betts, R.; Fahey, D.W.; Haywood, J.; Lean, J.; Lowe, D.C.; Myhre, G.; Nganga, J.; Prinn, R.; Raga, G.; Schulz, M.; Van Dorland, R. 2007. Changes in atmospheric constituents and in radiative forcing. In Climate Change 2007: The Physical Science Basic. Contribution of Working Group I to the Fourth Assessment Report of the Intergovernmental Panel on Climate Change. Solomon, S; Quin, D; Manning, M; Chen, Z; Marquis, M; Averyt, KB; Tignor, M; Miller, HL. Eds.; Intergovernmental Panel on Climate Change: Cambridge, U.K. and New York.

Friedlingstein, P.; Solomon, S.; Plattner, G.K.; Knutti, R.; Clais, P.; Raupach, M.R. 2011. Long-term climate implications of twenty-first century options for carbon dioxide emission mitigation. Nature Climate Change 1:457-461.

Geng, H.; Yang, H.; Chen, J.; Hong, Y. 2017. Review of carbon storage function of harvested wood and the potential of wood substitution in greenhouse gas mitigation. Forest Policy and Economics 85(1):192-200.

Giordano, G. 1997. Wood anthology. (In Italian). Consorzio LegnoLegno, Reggio Emilia.

Hansen, J.; Johnson, D.; Lacis, A.; Lebedeff, S.; Lee, P.; Rind, D.; Russell, G. 1981. Climate inpact of increasing climate change. Science 213(4511):957-966.

Houghton, J. 2015. Global warming: the complete briefing. $5^{\text {th }}$ edition. Cambridge Univerisy Press, Cambridge. 
International Panel on Climate Change. 2014: Climate Change 2014: Synthesis Report. Contribution of Working Groups I, II and III to the Fifth Assessment Report of the Intergovernmental Panel on Climate Change [Core Writing Team, R.K. Pachauri and L.A. Meyer (eds.)]. IPCC, Geneva, Switzerland, $151 \mathrm{pp}$.

Kurt, R.; Cil, M. 2012. Effects of press pressure on glue line thickness and properties of laminated veneer lumber glued with melamine urea formaldehyde adhesive. Bioresources 7(3):4341-4349.

Lippke, B.; Oneil, E.; Harrison, R.; Skog, K.; Gustavsson, L., Sathre, R. 2011. Life cycle impacts of forest management and wood utilization on carbon mitigation: Knowns and unknowns. Carbon Management 2(3):303-333.

McKeever, D.B.; Elling, J. 2015. Wood products and other building materials used in new residential construction in the United States, with comparison to previous studies 2012. Tacoma, WA: APA - The Engineered Wood Assoc. 75p.

McKinley, D.C.; Ryan, M.G.; Birdsey, R.A.; Giardina, C.P.; Harmon, M.E.; Heath, L.S.; Houghton, R.A.; Jackson, R.B.; Morrison, J.F.; Murray, B.C.; Pataki, D.E.; Skog, K.E. 2011. A synthesis of current knowledge on forests and carbon storage in the United States. Ecological Applications 21(6): 1902-1924.

Meil, J.; Lippke, B.; Perez-Garcia, J.; Bowyer, J.; Wilson, J. 2004. Environmental impacts of a single family building shell-From harvest to construction. CORRIM: Phase I Final Report: Module J. University of Washington, Seattle, WA. 38p.

Miner, R.A.; Abt, R.C.; Bowyer, J.L.; Buford, M.A.; Malmsheimer, R.W.; O'Laughlin, J.; Oneil, E.E.; Sedjo, R.A.; Skog, K.E. 2014. Forest carbon accounting considerations in US bioenergy policy. Journal of Forestry 112(6):591-606.

National Oceanic and Atmospheric Administration. NOAA. 2018. The NOAA annual greenhouse gas index (AGGI). (NOAA) Earth System Research Laboratory Boulder, CO. <http:// www.esrl.noaa.gov/gmd/ccgg/trends/global.html> (accessed on 07.05.2018).

O'Connor, J. 2004. Survey on actual service lives for North American buildings. In: Presented at the Proceedings of Woodframe Housing Durability and Disaster Issues Conference. October 4-6, 2004. Las Vegas, Nevada; Forest Products Society, Madison, Wisconsin.

Pachauri, R.K.; Allen, M.R.; Barros, V.R.; Broome, J.; Cramer, W.; Christ, R.; Church, J.A.; Clarke, L.; Dahe, Q.; Dasgputa, P.; Dubash, N.K.; Edenhofer, O.; Elgizouli, I.; Field, C.B.; Forster, P.; Friedlingstein, P.; Fuglestvedt, J.; Gomez-Echeverri, L.; Hallegatte, S.; Hegerl, G.; Hownden, M.; Jiang, K.; Jimenez Cisneroz, B.; Kattsov, V.; Lee, H.; Mach, K.J.; Marotzke, J.; Mastrandrea, M.D.; Meyer, L.; Minx, J.; Mulugetta, Y.; O'Brien, K.; Oppenheimer, M.; Pereira, J.J.; Pichs-Madruga, R.; Plattner, G.K.; Pörtner, H.O.; Power, S.B.; Preston, B.; Ravindranath, N.H.; Reisinger, A.; Riahi, K.; Rusticucci, M.; Scholes, R.; Seyboth, K.; Sokona, Y.; Stavins, R.; Stocker, T.F.; Tschakert, P.; Van Vuuren, D.; Van Ypserle, J.P. 2014. Climate Change 2014: Synthesis Report. Contribution of Working Groups I, II and III to the Fifth Assessment Report of the Intergovernmental Panel on Climate Change / R. Pachauri and L. Meyer (editors), Geneva, Switzerland, IPCC, 151 p. ISBN: 978-92-9169-143-2.

Pilli, R.; Fiorese, G.; Grassi, G. 2015. EU mitigation potential of harvested wood products. Carbon Balance and Management 10:6

Ramage, M.H.; Burridge, H.; Busse-Wicher, M.; Fereday, G.; Reynolds, T.; Shah, D.U.; Wu, G.; Yu, L.; Fleming, P.; Densley-Tingley, D.; Allwood, J.; Dupree, P.; Linden, P.F.; Scherman, O. 2017. The wood from the trees: the use of timber in construction. Renewable and Sustainable Energy Review 68(1):333-359. 
Resch, H. 2008. Considering changes in wood utilization - A European perspective. MaderasCienc Tecnol 10(1):61-68.

Salazar, J.; Bergman, R. 2013. Temporal considerations of carbon sequestration in LCA. In: Proceedings from the LCA XIII Conference, October 1-3, 2013, Orlando, FL: 136-142.

SCRIPPS. 2018. The keeling curve. Available at $<$ https://scripps.ucsd.edu/programs/keelingcurve/ $>$ (accessed on 02.12.2018).

Simpson, W.T. 1993. Specific gravity, moisture content, and density relationship for wood. U.S. Department of Agriculture, Forest Service, Forest Products Laboratory, Madison.

Skog, K.E. 2008. Sequestration of carbon in harvested wood products for the United States. Forest Products Journal 58(6):56-72.

Smith, J.E.; Heath, L.S.; Skog, K.E.; Birdsey, R.A. 2006. Methods for calculating forest ecosystem and harvested carbon with standard estimates for forest types of the United States. General Technical Report NE-343. Newtown Square, Pennsylvania: U.S. Department of Agriculture, Forest Service, Northeastern Research Station, Newtown Square, Pennsylvania. 216p.

Takano, A.; Hafner, A.; Linkosalmi, L.; Ott, S.; Hughes, M.; Winter, S. 2015. Life cycle assessment of wood construction according to the normative standards. European Journal of Wood and Wood Products 73(3):299-312.

Theomen, H.; Irle, M.; Sernek, M. 2010. Wood-based panels. An introduction for specialists. Brunel University Press, London.

Thomas, D.C. 2001. Carbon dioxide mitigation: a challenge for the twenty-first century. In: Carbon Management: Implications for R\&D in the Chemical Sciences and Technology: A Workshop Report to the Chemical Sciences Roundtable. National Academies Press (US), Washington (DC).

Thomas, S.C.; Martin, A.R. 2012. Carbon Content of Tree Tissues: A Synthesis. Forests 3(2):332352.

Thonemann, N.; Schumann, M. 2016. Environmental impacts of wood-based products under consideration for cascade utilization: a systematic literature review. Journal of Cleaner Production 172(2018):4181-4188.

United States Department of Commerce. 2017. Characteristics of new housing. Available $<$ https://www.census.gov/construction/chars/pdf/c25ann2016.pdf.>

Vitale, P.; Arena, U. 2018. An attributional life cycle assessment for an Italian residential multifamily building. Environmental Technology 39(23): 3033-3045.

Wellons, J.D.; Krahmer, R.L.; Sandoe, M.D.; Jokerst, R.W. 1983. Thickness loss in hot-pressed plywood. Forest Products Journal 33(1):27-34.

Wang, B.J.; Ellis, S.; Dai, C. 2006. Veneer surface roughness and compressibility pertaining to plywood/LVL manufacturing. Part II. Optimum panel densification. Wood and Fiber Science 38(4):727-735.

Williamson, P. 2016. Emissions reduction: scrutinize $\mathrm{CO}_{2}$ removal methods. Nature 530:153-155.

Wilson, J.B. 2010a. Life-cycle inventory of particleboard in terms of resources, emissions, energy and carbon. Wood and Fiber Science 42(CORRIM Special Issue):90-106. 
Wilson, J.B. 2010b. Life-cycle inventory of medium density fiberboard in terms of resources, emissions, energy and carbon. Wood and Fiber Science 42(CORRIM Special Issue):107-124. 